\title{
MODERATING THE EFFECT OF ORGANISATIONAL CULTURE ON EMPLOYEE MOVEMENT AND SUSTAINABILITY OF NIGERIAN COMMERCIAL BANKS
}

\author{
MORGAN OBONG MORGAN*1, EMMANUEL EKPENYONG OKON ${ }^{1}$, WINIFRED HARRY \\ EMU $^{2}$ AND HOPE UKAM EDODI ${ }^{1}$
}

${ }^{1}$ Department of Business Management, Faculty of Management Sciences, University of Calabar, Nigeria. ${ }^{2}$ Department of Educational Management, Faculty of Education, University of Calabar, Calabar, Nigeria.

*Corresponding author: m_morgan24@yahoo.com

Submitted final draft: 21 November $2020 \quad$ Accepted: 7 January $2021 \quad$ http://doi.org/10.46754/jssm.2021.10.006

\begin{abstract}
Sustainability of commercial banks in Nigeria has, in recent decades, been threatened by the increasing mass exodus of employee movement due largely to the seemly lack of job security, poor remuneration, management style, and growing organisational culture in commercial banks, which tends to give impetus to this conundrum. The purpose of this study was to examine the moderating effect of organisational culture on employee movement and the sustainability of commercial banks in Nigeria. This study thoroughly evaluated the relationship between three variables that act as catalysts to employee movement in Nigerian Commercial banks, i.e. job security, remuneration and management style, and the moderating effect of organisational culture. A survey was developed for the study on selected commercial banks. The population of the study was 986 and a sample size of 285 was determined to be appropriate for the study using the Taro Yamane formula. Data were collected from 285 employees from the selected banks using a questionnaire. The study employed the descriptive statistic and multiple regression analysis for the test of the hypotheses, while Confirmatory Factor Analysis (CFA) was used to provide complete validation of the constructs in the measurement model. The study found that employee movement has a significant effect on the sustainability of Nigerian commercial banks. Specifically, employee movement constructs, such as job security, remuneration, and management style, had significant effects on the sustainability of the Nigerian commercial banks. Furthermore, organisational culture has a significant moderating effect on the relationship between employee movement and the sustainability of commercial banks. The managerial implication of the study is that the negative effect of employee movement on the sustainability of the Nigerian commercial banks can be addressed by adopting and implementing an employee-friendly organisational culture.
\end{abstract}

Keywords: Sustainability, employee movement, organisational culture.

\section{Introduction}

In an era of global competition among financial institutions and the challenges faced by commercial banks due to the COVID-19 pandemic and other economic upheavals affecting nations, especially developing countries and Nigeria in particular, the sustainability of commercial banks is germane to support the nation's economic recovery and growth. However, the sustainability of commercial banks in Nigeria has, in recent times, been threatened by the increasing spate of employee movement due largely to the seemingly lack of job security, poor remuneration, management style, and a growing organisational culture that is giving impetus to this conundrum, leading to a situation where highly skilled and experienced employees move out of commercial banks to other sectors in search of job security, better remuneration, and efficient management.

Nqwenelwa (2013) indicated that the rate of employee movement in commercial banks is alarming and is becoming a growing concern for stakeholders because of its impact on organisational operations and sustainability. Employee movement is the frequency at which employees come into an organisation in terms of job engagement or employment and exit an 
organisation in the form of dismissal or in search for greener pastures over some time (Pietersen $\&$ Oni, 2014). Meanwhile, the sustainability of commercial banks is the ability of the bank to maintain its employees effectively and operate in an environmentally, socially and economically acceptable way, and continues to operate over a long period (Renata, 2019). The continuous increase in employee movement in commercial banks in Nigeria has been attributed to job insecurity, poor remuneration, lack of adoption of efficient management style, sacks/layoffs, downsizing and a growing organisational culture with its attended consequences on organisational operations; either increased training cost to replace exit employees or technological transfers and banks security.

Furthermore, organisational culture plays a critical role in guiding the activities and operations of firms. It encompasses the philosophy, beliefs, values, and the guiding principles governing the behaviour of people (employees) and their activities (Girma, 2019). The organisational culture of commercial banks is central to employee movement intentions and influences the behaviour and attitudinal disposition of employees; its relationship with co-workers, customers, and its operations, as well as in determining the bank's success and sustainability. Unfortunately, most commercial banks pay little attention to the influence of the organizational culture in reducing employee movement to enhance the bank's performance and sustainability. This situation leads to employees' search for secure and better-remunerated employment, giving rise to frequent movement of employees in commercial banks.

Similarly, the organisational culture of commercial banks has a profound influence on employees, their operations, and practices (Mutua \& Simba, 2017). Its influence is felt and expressed daily in the way employees interact and operate, the intentions of employees to leave the bank as well as the management attitude in addressing such issues. The poor attitude and behaviour of management in addressing the issues and factors contributing to employee movements, such as job insecurity, poor remuneration, and management style, have raised concern. It explains why employee movement has continued in commercial banks for decades unabated, despite the influence of such practices on a bank's operations, performance and sustainability, and why specific customs and beliefs are shared among workers.

One pertinent problem that affects the performance and sustainability of commercial banks, and one that encourages employee movement, is the issue of job security, where employees are constantly in search of lifelong employment and opportunities for career advancement. Additionally, another important issue related to employee movement is the lack of efficient management style, where commercial bank managements do not adopt an inclusive management style that gives employee the opportunity to make contributions to a large extent in decision-making and policymaking process. Hence, giving employees a sense of belonging will have an impact on the performance and sustainability of a firm's operations. The issue of remuneration in terms of competitive salaries for bank workers in recent years has been observed as one of the fundamental factors of employee movement. The salary structure and other benefits should be able to attract employee, retain and motivate them, which discourages them from leaving an organisation. Therefore, the numerous inconsistencies in studies regarding the exact effect of employee movement on sustainability prompted the study to empirically examine the moderating effect of organisational culture on the relationship between employee movement and sustainability of Nigerian commercial banks.

\section{Literature Review}

\section{Theoretical Background}

The theoretical foundation of this study hinged on the four systems of management theory, and Vroom's valence and expectancy theory. The theories form the underpinnings of the study and highlight the relationship between the variables. 


\section{System Four Management Theory}

Renesis Likert, an organisational psychologist, is well known for his leading studies on management style (Likert, 1967). He developed the Likert scale and the linking pin model of management theory (Batermen \& Snell, 1999). He conducted much research on human behaviour as expressed in the workplace within organisations. He appraised various types of management/leadership styles and postulated that to accomplish required profitability, high productivity, effective workplace coordination, harmony, and good staff relations, every organisation must optimise the utilisation of its human capital. After extensive research on human behaviour within many organisations, Likert (1967) concluded that there are four basic management systems. He stressed that the effectiveness, efficiency, and sustainability of a firm or its departments is mostly influenced by its management system. He characterised these four systems as:

Exploitative-authoritative management system: Here, decisions are imposed and subordinates do not participate in the decisionmaking processes. Motivation is characterised by threats and the organisation uses fear and intimidation to ensure employees complete their tasks. Here, responsibilities are on top management levels, while subordinates practically have none. There is very limited or poor organisational communication with less teamwork. This situation discourages employees and lowers workers' morale, performance, and leads to employee movement (Ian \& Jonathan, 2007).

Benevolent-authoritative management system: In this system. leadership condescends in the structure of master-servant conviction. Motivation is principally by reward and administrative staff takes full liability, while the subordinates do not. There are limited organisational communication and relatively poor employee team spirit and teamwork.

Consultative management system: In this system. superiors provide leadership and tend to have some but not complete confidence in their subordinates. Motivation is substantially by rewards and there is a level of worker participation in decision-making processes. Top-level personnel shoulder the responsibility for attaining the organisation's goals and objectives, though management constructively uses subordinates' opinions and ideas. However, while there is some level of employee involvement in this system, major decisions still rest on the senior management (Effiom, \& Anietie, 2018).

Participative group management system: This is the leading system where superiors and management have total conviction in subordinates. Motivation is through economic rewards as a result of goals accomplished. Employees at every level of the organisation take full responsibility for accomplishing the organisation's goals and objectives. There is free flow of information within the organisation, and subordinates fully participate in the decisionmaking processes as they comfortably express their ideas and opinions. Staff interrelationship and cooperative teamwork is the norm in this system. Group teams are connected by employees who maintain membership in several associations with colleagues to enhance the performance and sustainability of the firm.

To attain optimum staff productivity and organisational sustainability, managers need to adopt an effective management system that enhances employees' participation in decisionmaking processes and flow of information, while discouraging frequent employee movement from the organisation (Meaghan \& Nick, 2002). However, the four systems theories are not without criticism. Critics question the simplistic notion that a "happy worker is a productive worker". This notion, of course, ignores the workers' rational side, as well as thr eminent and influential characteristics of the formal organization (Baterman \& Snell, 1999).

Also, Likert's assertion of the ideal organisation as an effective organisation has been criticised for being too simplistic about the complex nature of the problem of effectiveness. Thus, there has been an increasing 
acknowledgment that paying much attention to generic elements could disguise the fact that there are contrasting features and views of organisational effectiveness. Likert emphasises that effective organisation is a function of staff supportive relationship, which, if fostered, would discourage employee movement and boost employee's sense of personal value and worth. The axiom of this management variable is that some leadership styles do foster workplace harmony in achieving high productivity and organisational sustainability, while others may demotivate, trigger strive, conflict, and employee movement.

\section{Vroom's Valence and Expectancy Theory}

Vroom (1964) propounded a motivation theory based on three major components: expectancy, instrumentality, and valence. The theory was established on the conception that motivation is determined by an employee's expectation that work efforts contribute to performance, while performance enhances work outcomes, and this in turn determines the desired job rewards. He opined that a worker would oftentimes exert a high level of work effort, i.e. if they perceive a strong association between work exertion, work performance, and job rewards, and also work rewards and personal goal satisfaction which they seek (Chowdhury \& Nazmul, 2017). Vroom contends that a person's motivation is a function of expectancy that an outcome would follow behaviour, which relates to how the individual perceives the rewards.

However, valences and expectancies are subject to an employee's perception of the circumstance. For instance, the belief that if they exert more effort, that is work harder, they will get promoted or a raise in remuneration, which is expectancy and the valence is the attractiveness value of the desired outcome (how strongly he wants the outcome: promotion or pay raise). Implicit from the analysis is that dissatisfaction; frustration; job insecurity; feeling of alienation; emotional bitterness and anger; and. eventual employee movement usually result from the inability of the organisation to meet employee expectancy (Nyaga, 2015). This situation leads to employee movement and influences organisational performance and sustainability.

\section{Employee Movement}

The issue of frequent employee movement has continued to be a phenomenon of concern to management and stakeholders in the banking sector because of its effect on commercial banks' operations, performance, and sustainability in the long run. Employee movement is the frequent movement of workers in and out of commercial banks (Pietersen \& Oni, 2014). It is a situation where employees often move out of commercial banks in search of better job security, good remuneration, and effective management style, among others (Ade et al., 2015). Price (1997) views employee movement as the proportional relationship between employees in an organisation who depart within a period divided by the number of staff in that enterprise within the same period. Each time an employee moves out of a commercial bank to another organisation, whether willingly or unwillingly, new staff must be employed and trained to fill the gap of the departed employee and such employee movement causes serious disruption on the operations of the organisation and increases the recruitment and training costs of the organisation (Rasoava, 2015).

According to Armstrong (2009), employee movement is the rate of staff leaving an enterprise through attrition, sacking, or resignation within the period under review to the number of staff in the firm's payroll within the same period. Tamunomeibi (2003) defines employee movement as the rate at which an organisation gains or loses staff. Marwan et al. (2016) see employee movement as a measure of the level at which already existing employees exit an organisation and new entrants gain access into the service of the firm in a given period. Also, Meier and Hicklin (2007) view employee movement as the frequency at which an organisation brings in and loses employees. In other words, employee movement may be defined as the total figure or proportion of 
employees who depart from an organisation and are replaced by newly recruited employees over a period of time (Shinwoo, 2018).

However, some employee movements are acceptable in commercial banks, especially in a situation where entrants into the organisation bring innovations or enable the bank to substitute employees who no longer have anything useful to offer. This is because fusing new talent in the bank re-energises the workplace and boosts the production capacity, returns on investment, and sustainability of the bank (Francis, 2015). Furthermore, in the face of financial constraints and other challenges, most commercial banks decide to reduce their staff strength to a size they can comfortably and conveniently accommodate. Those who also decide to maintain the status quo do so by reviewing employees' salaries downwards to accommodate them. Employees are constantly under pressure and threatened with job loss should they fail to meet set targets in commercial banks. This dampens employee morale, leading to increased concern about job security, which affects workers' productivity and sustainability. These increasing concerns about job security and other benefits in commercial banks have caused increased employee movement from commercial banks to public sector organisations, where job security is guaranteed, the pay notwithstanding (Nyaga, 2015). Successfully resolving the challenges of employee movement and decisively tackling the factors that motivate employees out of the organisation require organisational cultural backings. An organisation's cultural value strongly varies among firms. The relationship that exists between employee job performance and his retention varies with each organisation's cultural values (Eric, 2018). Employees mostly get attracted to and cling to employment in organisations they perceive to be compatible with their values. Objectively, high employee movement significantly affects commercial banks' performance and this has impact on its long term sustainability.

Furthermore, most business organisations, particularly commercial banks, failed to adopt appropriate strategies to resolve issues with regards to employee job security, remuneration, and management style to reduce the rate of employee movement and maintain skilled/ experienced staff. As employees exit an organisation, there is typically a need to fill the gap to not allow disruptions in the operations. The cost of this need is two-fold; the financial and technical cost of recruitment, selection, and training, which tends to escalate when staffing exercises are carried out frequently (Idiegbeyan-Ose et al., 2018). Similarly, the exit of highly skilled staff with specialised knowledge, especially when it occurs abruptly, often disrupts bank operations. Equipping the replacement adequately for the job calls for experiences on training so that new employees sufficiently cope with technology to which that they may not have been exposed. The capacity and readiness to receive training with the new technology needed may sometimes be lacking in the replacement staff. All these have consequences and implications for commercial banks' performance and sustainability (Girma, 2019).

Tamunomiebi (2003) distinguishes employee movement to be both internal and external. Internal employee movement has to do with employees coming into an organisation or internally transferred from one office to another within an organisation, while external employee movement involves employees leaving an enterprise to other organisations. Some internal employee movement produces some reward, such as increased morale, knowledge sharing, and improved relationship among employees. However, a high level of external employee movement affects the performance of workers, organisations, and the impact on the sustainability of commercial banks. Employee movement influences performance and commercial banks' sustainability (Chowdhury \& Nazmul, 2017). As indicated by Naidoo (2018), when an experienced and skilful employee leaves a commercial bank, there is often disruption and disconnections among workers, and whoever is drafted to fill the gap is required to undergo training for the new tasks and the techniques required to carry out the new assignment and 
this is often a cost to the bank. Also, such banks often encounter a loss of essential organisational knowledge when a skilful and experienced employee leaves the bank (Anders \& Bard, 2010).

However, employee movement could be measured at the individual firms or at the industrial level. Employee movement hurts an organisation's productivity, particularly in commercial banks when experienced employees leave too frequently and the existing workforce contains a high proportion of inexperienced and newly recruited employees (Anders \& Bard, 2010). Employee movement may be willingly or unwillingly stimulated. Willing employee movement is movement at the volition of an employee, whereas unwilling employee movement involves involuntary or automatic disengagement, layoff, retirement, downsizing, or sacking (Steers \& Porter, 1991). A typical example of an organisation's planned employee movement was the 2004 bank recapitalisation in Nigeria, which brought about the merger of several commercial banks, leading to a large movement of employees out of banks and disruptions to the bank's operations and sustainability (Zeeshan et al., 2016).

Similarly, Steers and Porter (1991) believe that employee movement also causes organisational effectiveness to be reduced if workers cannot stay on the job as expected by the organisation and gain the needed experience on the job. Testa (2008) reveals that frequent employee movement of capable/talented employees is detrimental and can cause serious problems to an organisation. Also, experienced and skilful employees who leave one bank may be re-employed by a competing bank and this could bring about a competing advantage for one bank over the other. As indicated by Ubeku (1975), increased employee movement may lead to a leak of critical or classified information to other organisations or private individuals, which may be detrimental to a firm's performance. Also, increased employee movement in an organisation serves as motivation to other employees to continuously search for jobs with enhanced job security and remuneration and then exit their organisations (Ian \& Jonathan, 2007). Similarly, Testa (2008) asserted that the financial implication of employing a sound and competent staff is significant since the replacement of departed employees implies that the new staff should be able to replace the existing employee effectively by being able to fit into the vacuum and execute the task required efficiently. To have a perfect replacement, the organisation should be able to train the new entrant on the new job and this increases the training cost of the organisation (Kunu et al., 2017).

However, commercial banks require skilled and experienced employees in all the departments to enhance a seamless operation. When the right skill mix is available and retained, the objectives of the bank could be achieved more effectively because the attitudes of employees will be coordinated towards achieving predetermined goals (Olusegun, 2012). Although employee movement increases administrative costs, interrupts the bank's operations, work in progress, and causes technical adversity to the organisation, there are benefits attributed to it, if the employee movement is carefully planned. These benefits include the replacement of underperforming employees with skilful and innovative talent (Adnan, 2010). According to Meaghan and Nick (2002), planned employee movement by a firm can be a viable means of organisational transformation. More knowledgeable workers with lower salaries could replace underperforming staff with huge wage liability. Under this arrangement, the organisation may experience some kind of transformational reorganisation and unification of several positions, which can improve organisational productivity. However, Hill (1979) contended that frequent employee movement has serious implications on the performance and sustainability of firms. Also, a study by Santript and Ambalika (2013) indicated that increased employee movement has serious implications for organisational performance and sustainability. Again, Ali (2015) indicated that frequent exit of the experienced employee in organisations has a significant negative effect 
on the firm's overall productivity and longterm sustainability. Therefore, for organisations, particularly commercial banks, to address issues such as job insecurity, employee remuneration, and management style, they need to reduce the motivation for employee movement and retain skilful and experienced employees in the organisation for improved performance and sustainability of commercial banks.

\section{Sustainability}

Sustainability of enterprises, particularly financial institutions such as banks, is important because of the significant role they play in enhancing economic growth in any nation. Sustainability of commercial banks is the ability of financial institutions to operate in an environmentally, socially, and economically acceptable way while maintaining its human resources and carry out its activities innovatively and creatively to exist over a long period (Renata, 2019). It is a business approach, where financial institutions operate their business to create long-term value profitably by reducing harm to employees, society, economics, and the environment. Enterprise sustainability, particularly financial institutions are critical to the long-term stability, prosperity, and economic growth of a nation. Sustainability of financial institutions enables commercial banks to maximise their opportunities while minimising the negative impact of its operations on the environment, the society, and on the employees, which could trigger employee intention and eventually lead to employee movement in the firm (David \& Sebastian, 2016).

According to Stankevicienea and Nikonorova (2014), long-term sustainability of commercial banks enables the banks to maintain and manage its operations, customers and employees efficiently to enhance the bank's long-term sustainability and reduce employee movement in and out of the bank with its accompanying consequences. Focusing on building sustainable employees has several benefits and significantly reduces employee movement. Building sustainable employees in commercial banks enhances the efficiency and skills of workers in financial transactions over a long period, and it enhances security, and reduces the rate of worker's movement, as well as training costs for new employees. Increasingly, commercial banks in Nigeria are taking strategic decisions on their organisational culture to support their business sustainability and reduce employee movement. The culture of an enterprise plays a vital role in reducing employee movement while also enhancing its sustainability (Tommasetti et al., 2019). The organisational culture of commercial banks is the values, customs, and philosophy governing the operations of banks, including the attitude and behaviour of management towards issues that lead to workers' movement (Francis, 2015).

The concept of enterprise sustainability in commercial banks has continued to gain wide acceptability and applicability because of its significant role in minimising the negative impact of bank operations on the environment, society, build sustainable employees and reduce workers' movement in the enterprise (Wong et al., 2016). Embracing sustainability enables commercial banks to meet customers' expectations, boost business efficiency, motivate employees, enhance reward for good behaviour, reduce worker's movement, and improve environmental, social, and economic performance. Therefore, the integration of sustainability ideology into commercial banks' business practices is becoming a mainstay to enhance commercial banks' success by building sustainable employee over a long term.

\section{Organisational Climate and Employee Movement}

The organisational culture of enterprises influences the performance, sustainability, and employee movement of firms because the culture of an organisation influences the activities and behaviour of employees and management (Mutua \& Simba, 2017). Organisational culture serves as a guiding principle, philosophy, beliefs, and values that affect the behaviour, attitude and actions of management and employees in an organisation (Girma, 2019). The organisational 
culture of a firm, particularly commercial banks, is pivotal to employee movement and influences organisational performance and sustainability (Idiegbeyan-Ose, et al., 2018).

An organisational culture that values employees may have a positive impact on employee movement compared with a culture that pays little to no attention to the value of employees (Eric, 2018). Organisational culture also affects the manner in which employees relate how knowledge is shared, and how operations of the firm are organised and executed. It encompasses shared beliefs, values, and ideologies that guide the actions of workers, including actions and intentions that lead to employee movement (Bosomtwe \& Obeng, 2018). An organisational culture that fails to check salient issues, such as job security, remuneration, and management style, may encourage employee movement in an enterprise.

Organisational culture refers to peoples' behaviour that is an integral part of an organisational setting and defines the connotations humans attach to their actions (Esra et al., 2011). It is an expression and symbolisation of an organisation's visions, values, beliefs, norms, and ethics among employees. It defines the collective behavioural pattern and assumptions inculcated into members of the firm, as well as how they relate and interact with one another in the organisation with the aim of enhancing performance and a firm's sustainability. Ravasi and Schultz (2006) posited that a firm's culture is the shared mental suppositions that direct the firm's decisions by describing adequate behaviour for various situations. There is no universal organisational culture since it varies from one organisation to another. Organisations have different cultures and subcultures, which influence the behaviour of people (Kotter \& Heskett, 1992; Deal \& Kennedy, 2000).

An organisation's cultural value strongly varies among firms. The correlation that exists between a worker's job performance and his retention or intention to move from one organisation to another varies with each organisation's cultural values (Linz et al., 2006; Dessler, 2008; Michael \& Crispen, 2009). Issues related to workers' job security, remuneration, management style, and other human resource issues are indeed strongly influenced by the organisation's cultural value (Osibanjo \& Adeniji, 2013). Employees mostly get attracted to and cling to employment in organisations they perceive to be compatible with their values. Organisations with little or no job security, poor remuneration, and lack of effective management styles are likely to witness high employee movement, which could influence organisational performance and sustainability (Nnamani \& Agu, 2012).

Firms must continually strive for healthy, robust, and performance-oriented organisational cultures that promote efficiency and discourages frequent employee movement in order to enhance organisational sustainability, particularly in commercial banks. Amah and Daminabo-Weje (2013) posited that firms with flexible culture accomplish their goals better than firms with inflexible culture. A flexible culture allows for the initiation of changes that tend to address topical issues, such as frequent employee movement, which may impact the operational performance of a firm, while an inflexible culture reduces organisational effectiveness and productivity. Bosomtwe and Obeng (2018) further posit that the longterm goal achievement of an organisation's cultural policy significantly correlates with the organisation's performance and sustainability. Eric (2018) indicated that organisational culture impacts employee movement, performance, and sustainability of the firm. Therefore, firms need to pay special attention to their organisational culture because of its impact on worker's behaviour and actions, which could impact on the sustainability of firms.

\section{Employee Movement and Sustainability of Commercial Banks in Nigeria}

Due to increasing competition, particularly in the financial sector, the sustainability of commercial banks depends not only on its 
financial performance and technology, but to a large extent on its employees. This is because the employees are the building block of any organisation in which they utilise their skills and expertise in an innovative and creative way to carry out activities effectively and enhance the sustainability of banks in the long run (Pietersen \& Oni, 2014). Employees of commercial banks are often challenged to acquire, expensive to train and sustain, and difficult to retain due to the seemingly lack of job security, poor remuneration, and management styles of some commercial bank managers in Nigeria. This situation leads to frequent employee movement in commercial banks, which affects their performance and sustainability. Thus, it is pertinent to emphasise that commercial banks' ability to retain their skilled employees and reduce frequent employee movement is strategic to its long-term sustainability (Ade et al., 2015). There is no doubt that the performance and sustainability of commercial banks are very germane to the economic development and growth of any nation. However, commercial banks in Nigeria have over the years been faced with frequent employee movement, and this leads to poor performance over a long period of time. When an employee moves out of a commercial bank, present employees have to fill the gap until a new employee is appointed and trained to resume the duties of the departed employee. Employee movement out of a commercial bank has an impact on workers' performance because their daily work routines are disrupted and also morale is lowered (Ian \& Jonathan, 2007).

Consequently, when experienced employees move out of commercial banks, they often take away valuable operational knowledge or intellectual assets with them. Seasoned bankers with proven experience and expertise serve as morale boosters for work teams and help new or younger staff progress quickly and understand the operational intricacies. Frequent employee movement forces managers to focus their attention on staffing rather than deploy their energy in strengthening other vital areas of operations. Incessant employee movement poses a challenge to the operations of commercial banks due to the sensitive nature of bank operations, which causes disruption to workers' output and organisational performance and sustainability. Despite the huge implications of frequent employee movement, some movement is inevitable and acceptable, particularly when it is planned and properly managed by the bank management, which is targeted at filling the skill and expertise gap. However, some employee movements could severely reduce workers' morale, bank performance, and customers' patronage, damage the bank's reputation and have a negative impact on the sustainability of the bank (Tamunomiebi, 2003).

Furthermore, employee movement may arise due to job insecurity, poor remuneration, poor management style, disengagement, redeployment, dismissal, retirements, or layoffs, which is often detrimental to the effectiveness of employees and weakens banks' operational efficiency (Ali, 2015). According to Naidoo (2018), most of the times, frequent employee movement in commercial banks destabilise the social pattern of relationships among employees and teams as skilful and experienced employees move out of commercial banks, and this has an impact, to a large extent, on the productivity of workers. This situation has the potential of raising concerns among co-workers, as well as negative perceptions about job security, remuneration, and management style, which may damage the bank's reputation and customer patronage. As employees frequently move out of commercial banks, the operational efficiency of the banks is likely to drop, owing to the operational vacuum created (Francis, 2015).

Similarly, workers' productivity and commitment, which constitute the major propellants that accelerate performance in commercial banks, tend to diminish as employees become threatened by the unceasing movement by employees from commercial banks (Linz et al., 2006). Also, adaptation to banks' operational technologies and technological transfer/ knowledge is often impacted when there is frequent employee movement in banks. In commercial banks, where professional bankers 
move out frequently, it becomes challenging for new employees to adapt quickly to the bank's operation and other job responsibilities, while the procedural transfer of knowledge is completely eroded. This situation increases training costs and reduces funds, which could have been invested in other part of the bank's operations (Obiero, 2014).

According to Nqwenelwa (2013), frequent movement of employees in and out of commercial banks could significantly influence the sustainability of commercial banks and lower the morale of workers, which will impact negatively on worker's performance and efficiency. However, a study by Effiom and Anietie (2018) found that increased employee movement influences worker's performance, reduces the morale of co-workers, and significantly influences long-term sustainability. Similarly, Ali (2015) found that frequent employee movement in commercial banks is attributed to a lack of job security and poor remuneration, and the situation leads to poor performance as skilled employees move out of the banks. Eric (2018) indicated that increased employee movement in and out of commercial banks have a negative impact on the efficiency of workers, as well as the bank's performance, which significantly influences the firm's longterm sustainability. Therefore, it becomes pertinent for commercial banks to pay particular attention to issues that drive the motivations for employee movement, such as job security, worker's remuneration and management styles, among others.

Figure 1 shows the conceptual framework and establishes the relationship between the variables. The independent variable employee movement was measured in the dimensions of job security, remuneration, and management style, and the dependent variable was sustainability, while organisational culture was used as the variable to moderate the relationship between employee movement and sustainability of commercial banks. The hypotheses of the study were stated thus:

$\mathrm{H}_{1}$ : Job security has a significant effect on the sustainability of commercial banks

$\mathrm{H}_{2}$ : Remuneration has a significant effect on the sustainability of commercial banks

$\mathrm{H}_{3}$ : Management style has a significant effect on the sustainability of commercial banks

$\mathrm{H}_{4}$ : Organisational culture has a significant moderating effect on the relationship between employee movement and sustainability of commercial banks

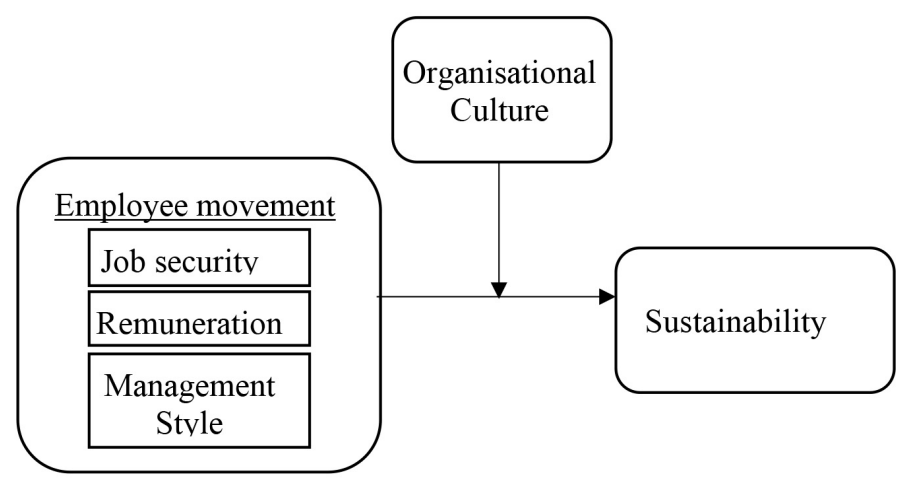

Figure 1: Conceptual framework 


\section{Method}

To plan systematically for the collection, analysis, and interpretation of data, the study employed a quantitative approach by utilising survey research design as the methodology for the study. The study population comprises 986 employees of the selected deposit money banks operating in Calabar, Cross River State. However, the sample frame for the study was 12 commercial banks operating in Calabar, Cross River State. The stratified sampling technique was used for the study. The commercial banks were divided into three strata of four banks each. The simple random technique was applied to select one bank from each stratum. At the end of the sampling exercise, three commercial banks that constitute the sample of this study were randomly selected. To determine the sample size in a logical and scientific manner, the Taro Yamene formula was applied to the population of the study to determine a sample size of 285 for the study. However, to select the actual respondents from each of the three selected commercial banks used for the study, a table of random numbers at an interval scale determined from the population of each commercial bank based on the sample size of the banks was used.

\section{Measurement}

A three-section, five-point structured Likerttype measurement instrument (questionnaire), ranging from one for strongly disagree to five for strongly agree, was developed and administered on the sampled employees in the selected banks to gather data for the study. Section A measured employee movement (job security, remuneration, and management style), Section B evaluated sustainability, and Section C focused on organizational culture. All the items that measured the constructs were adapted from empirical studies on employee movement and labour turnover. Section A of the instrument involves 15 items that measured employee movement; each dimension, job security, remuneration, and management style, had five items each and were adapted from a study by Francis (2015). The items in Section B, which evaluated sustainability, were adopted from Obiero (2014), while items that measured organisational culture in Section C were adapted from Nqwenelwa (2013). All the items adapted were modified to suit the present study. Descriptive statistics was used for data analysis, and multiple regression analysis was also used to test the hypotheses, while the Confirmatory Factor Analysis (CFA) was used to provide complete validation of constructs in the measurement model.

\section{Results and Discussion}

The necessary data screening, identification of missing values, and outlier analysis were performed. The outlier analysis was carried out using the Mahalanobis Distance $\left(\mathrm{D}^{2}\right)$ and five outliers were discovered after the analysis showed that five cases have a $\mathrm{D}^{2}$ probability value of above 0.001 , which indicated outliers and they were deleted. The remaining 280 cases that had values lower than 0.001 were retained and were used for the study. However, to ensure that the assumptions of the regression analysis were properly met, homoscedasticity and multicollinearity tests were performed.

\section{Confirmatory Factor Analysis (CFA)}

The CFA analysis was used to validate the instrument and determine whether the measures of the constructs were consistent and the data fit the measurement model. In CFA, items with factor loading of less than $(<0.50)$ were deleted from the model. Accordingly, to achieve the model fit, one item each in the job security, remuneration and sustainability constructs were deleted, while two items each in the management style and organisational culture constructs were deleted from the model due to the low factor loading as presented in Table 1.

According to Kline (2010), it is recommended to report the Root Mean Square Error of Approximation (RMSEA), Comparative Fit Index (CFI), Chi-Square test $\left(\chi^{2}\right)$, and Standardized Root Mean Square Residual (SRMR) to determine the goodness of fit of the measurement model. After the deletion, all the indices revealed that the model achieve 
goodness of fit $(\chi 2 / \mathrm{df}=2.11, \mathrm{RMSEA}=0.06$, $\mathrm{CFI}=0.94$ and $\mathrm{SRMR}=0.07)$ as the indicators were satisfactory and met the acceptable cut-off marks in all indices $(\chi 2 / \mathrm{df}<3$, RMSEA $<0.06$, $\mathrm{CFI}>0.9 \mathrm{SRMR}<.08)$. All the retained factor loading items exceeded the acceptable threshold of $(>0.50)$. The Cronbach's alpha ranged from $0.784-0.893$, which satisfactorily meets the recommended internal consistency value of $(>0.60)$. The Composite Reliability (CR) ranged from 0.769-0.889, and the Average Variance Extracted (AVE) ranged from 0.511-0.675, which exceeded the acceptable values of $(>0.60$ and $>0.50)$, respectively, in all the constructs, indicating that the model satisfactorily meets the recommended threshold.

Table 1: Summary of CFA result for the constructs $(\chi 2 / \mathrm{df}=2.11, \mathrm{RMSEA}=0.06, \mathrm{CFI}=0.94$ and $\mathrm{SRMR}=0.07)$

\begin{tabular}{|c|c|c|c|c|c|}
\hline \multirow[t]{2}{*}{ Variables } & \multirow[t]{2}{*}{ Item } & \multirow{2}{*}{$\begin{array}{c}\text { Factor } \\
\text { Loading }\end{array}$} & $\begin{array}{c}\text { Cronbach } \\
\text { Alpha }\end{array}$ & $\mathbf{C R}$ & AVE \\
\hline & & & 0.846 & 0.818 & 0.542 \\
\hline \multirow[t]{5}{*}{ Job Security (JS) } & JS1 & 0.81 & & & \\
\hline & JS2 & 0.78 & & & \\
\hline & JS3 & 0.76 & & & \\
\hline & JS4 & Deleted & & & \\
\hline & JS5 & 0.71 & 0.784 & 0.801 & 0.517 \\
\hline \multirow[t]{5}{*}{ Remuneration (R) } & R6 & 0.72 & & & \\
\hline & R7 & 0.75 & & & \\
\hline & $\mathrm{R} 8$ & Deleted & & & \\
\hline & R9 & 0.81 & & & \\
\hline & R10 & 0.82 & 0.821 & 0.833 & 0.589 \\
\hline \multirow[t]{6}{*}{ Management Style (MS) } & MS11 & 0.74 & & & \\
\hline & MS12 & Deleted & & & \\
\hline & MS13 & 0.86 & & & \\
\hline & MS13 & 0.77 & & & \\
\hline & MS14 & Deleted & & & \\
\hline & MS15 & 0.84 & 0.811 & 0.769 & 0.511 \\
\hline \multirow[t]{6}{*}{ Sustainability (S) } & S1 & 0.83 & 0.893 & 0.889 & 0.675 \\
\hline & $\mathrm{S} 2$ & 0.85 & & & \\
\hline & S3 & 0.82 & & & \\
\hline & S4 & 0.86 & & & \\
\hline & S5 & 0.87 & & & \\
\hline & S6 & Deleted & & & \\
\hline \multirow[t]{6}{*}{ Organisational Culture (OC) } & $\mathrm{OC} 1$ & 0.61 & 0.814 & 0.819 & 0.576 \\
\hline & OC2 & 0.69 & & & \\
\hline & OC3 & Deleted & & & \\
\hline & OC4 & 0.70 & & & \\
\hline & OC5 & 0.83 & & & \\
\hline & OC6 & Deleted & & & \\
\hline
\end{tabular}


In conducting the homoscedasticity test, Levene's test of equality of variances was conducted to determine if the variables were homoscedastic. The result of Levene's test in Table 2 indicated that the variance was homogeneous among the variables.

In conducting the multicollinearity test, tolerance value and Variance Inflation Factor (VIF) were used to establish whether there were very high intercorrelations among the predictor constructs. The rule of thumb is that tolerance should not be lower than 0.10 and VIF should not be above 10 (Hair et al., 2010). The result in Table 3 revealed that there were no multicollinearity issues as the tolerance value were all above .10 and VIF were far less than the cut-off value of 10 .

The analysis of the descriptive statistics test is presented in Table 4. The analysis revealed that job security as a measure of employee movement had a mean average value of 4.5632 with variance and standard deviation of 0.423 and 0.7545 , respectively, ranging from 2.00 to 5.00 as the minimum and maximum values, as well. Remuneration as an employee movement measure had an average value of 4.0231 , a variance value of 0.510 , and a standard deviation value of 0.7012 . Remuneration has 1.00 and 5.00 as its minimum and maximum values, respectively. Management style had an average

Table 2: Levene's test of homogeneity of variances

\begin{tabular}{lcccc}
\hline \multicolumn{1}{c}{ Constructs } & Levene Statistic & df1 & df2 & Sig. \\
\hline Job Security & 1.523 & 1 & 277 & .219 \\
Remuneration & .452 & 1 & 277 & .478 \\
Management Style & .289 & 1 & 277 & .589 \\
Organisational Culture & .384 & 1 & 277 & .469 \\
Sustainability & 1.921 & 1 & 277 & .246 \\
\hline
\end{tabular}

Table 3: Summary of collinearity statistics of variables

\begin{tabular}{lcc}
\hline \multirow{2}{*}{ Constructs } & \multicolumn{2}{c}{ Collinearity Statistics } \\
\cline { 2 - 3 } & Tolerance & VIF \\
\hline Job Security & .534 & 1.731 \\
Remuneration & .451 & 2.563 \\
Management Style & .545 & 1.912 \\
Organizational Culture & .467 & 1.932 \\
\hline
\end{tabular}

Table 4: Descriptive statistics of all the variables

\begin{tabular}{lcccccc}
\hline \multicolumn{1}{c}{ Variables } & N & Minimum & Maximum & Mean & $\begin{array}{c}\text { Std. } \\
\text { Deviation }\end{array}$ & Variance \\
\hline Job Security & 280 & 2 & 5 & 4.5632 & .7545 & .423 \\
Remuneration & 280 & 1 & 5 & 4.0231 & .7012 & .510 \\
Management Style & 280 & 2 & 5 & 4.2015 & .6224 & .601 \\
Sustainability & 280 & 1 & 5 & 4.1117 & .5812 & .458 \\
Organisational Culture & 280 & 1 & 4 & 4.3141 & .6452 & .466 \\
Valid N & 280 & & & & & \\
\hline
\end{tabular}


value of 4.2015, a standard deviation of 0.6224 , and a variance value of 0.601 ; with a range from a minimum value of 2.00 to a maximum value of 5.00. The descriptive statistics analysis further showed that the sustainability of Nigerian commercial banks had minimum value of 1.00 and the maximum value of 5.00. Its mean value was 4.1117 , a variance value of 0.458 , while its standard deviation was 0.5812 . Lastly, organisational culture had an average value of 4.3141, a variance value of 0.466 , and a standard deviation value of 0.6452 . Its minimum value was 1.00 , while its maximum value was 4.00 .

Table 5 shows the result of the correlation matrix analysis of the study variables. The correlation coefficient of the relationship between job security and remuneration of $\mathrm{r}=0.207$ revealed a positive correlation relationship between both variables and was found to be significant at a $1 \%$ significance level. The correlation coefficient of the relationship between job security and management style of $\mathrm{r}=0.197$ revealed a positive correlation relationship between both variables and was found to be significant at a $1 \%$ significance level. Furthermore, the correlation coefficient of the relationship between job security and the sustainability of $r=0.207$ revealed a positive correlation relationship between both variables and was found to be significant at a 5\% significance level. The correlation coefficient of the relationship between job security and organisational culture of $\mathrm{r}=-0.035$ revealed a negative correlation relationship between both variables and was found to be insignificant. The correlation coefficient of the relationship between remuneration and management style of $\mathrm{r}=0.311$ revealed a positive correlation relationship between both variables and was found to be significant at a $1 \%$ significance level.

Also, the correlation coefficient of the relationship between remuneration and sustainability of $\mathrm{r}=0.254$ revealed a positive correlation relationship between both variables and was found to be significant at a one percent significance level. The correlation coefficient of the relationship between remuneration and organisational culture of $\mathrm{r}=0.199$ revealed a positive correlation relationship between both variables and was found to be significant at a $1 \%$ significance level. Similarly, the correlation coefficient of the relationship between management style and sustainability of $\mathrm{r}=0.551$ revealed a positive correlation relationship between both variables and was found to be significant at a $1 \%$ significance level. Additionally, the correlation coefficient of the relationship between management style and organisational culture of $r=0.346$ revealed a positive correlation relationship between both variables and was found to be significant at a $1 \%$ significance level. Lastly, the correlation coefficient of the relationship between sustainability and organisational culture of $\mathrm{r}=0.512$ revealed a positive correlation relationship between both variables and was found to be significant at $1 \%$ significance level.

\section{Hypotheses Testing}

The regression analysis of the study was conducted to ascertain the relationship between the dependent variable (sustainability of

Table 5: Correlation matrix

\begin{tabular}{lccccc}
\hline \multicolumn{1}{c}{ Variables } & & & & & \\
\hline Job security & 1 & & & & \\
Remuneration & $.207^{* *}$ & 1 & & & \\
Management style & $.197^{* *}$ & $.311^{* *}$ & 1 & 1 & \\
Sustainability & $.149^{*}$ & $.254^{* *}$ & $.551^{* *}$ & $.512^{* *}$ & 1 \\
Organisational culture & -.035 & $.199^{* *}$ & $.346^{* *}$ & \\
\hline
\end{tabular}

*correlation is significant at the 0.05 level. ** Correlation is significant the 0.01 level 
Nigerian commercial banks), the explanatory variables (job security, remuneration, and management style) and the moderating variable (organisational culture). Without the moderating variable (organisational culture), given the result in Table 6 , the value of R2 $(0.835=83.5 \%)$ and the adjusted R2 $(0.833=83.3 \%)$, it was revealed that there is approximately an $83.5 \%$ and $83.3 \%$ variance in the sustainability of Nigerian commercial banks, which can be explained by factors such as job security, remuneration and management style, respectively. The remaining $16.5 \%$ and $16.7 \%$ variations in the sustainability of Nigerian commercial banks could be due to some other factors. The F-statistics value of 464.647 in Table 7, with its corresponding probability of 0.000 , showed that the relationship between employee movement and sustainability of Nigerian commercial bank's equation model was statistically significant at a $5 \%$ level of significance. Given the multiple regression results in Table 8, the constant variable revealed that employee movement (job security, remuneration, and management style) had a significant effect on the sustainability of Nigerian commercial banks. By implication, a unit change in employee movement affected significantly the sustainability of Nigerian commercial banks by 6.654 units as the case may be.

The explanatory variable job security has $(\beta=-0.409, p=.000)$, which implies that a unit change in job security would bring about a 0.409 -unit significant effect on the sustainability of Nigerian commercial banks. The second explanatory variable remuneration has $(\beta=$ $0.856, p=.000)$, which implies that a unit change

Table 6: Model summary

\begin{tabular}{cccccc}
\hline Model & R & R Square & Adjusted R Square & $\begin{array}{c}\text { Std. Error of the } \\
\text { Estimate }\end{array}$ & $\begin{array}{c}\text { Durbin- } \\
\text { Watson }\end{array}$ \\
\hline 1 & $.914^{\mathrm{a}}$ & .835 & .833 & 1.134 & .251 \\
\hline
\end{tabular}

a. Predictors: (Constant), Job security, remuneration, management style

b. Dependent Variable: Sustainability

Table 7: ANOVA $^{\mathrm{a}}$

\begin{tabular}{llccccc}
\hline & Model & Sum of Squares & Df & Mean Square & F & Sig. \\
\hline 1 & Regression & 1793.215 & 3 & 597.738 & 464.647 & $.000^{\mathrm{b}}$ \\
& Residual & 355.056 & 276 & 1.286 & & \\
& Total & 2148.271 & 279 & & & \\
\hline
\end{tabular}

a. Dependent Variable: Sustainability

b. Predictors: Job security, remuneration, management style

Table 8: Coefficients ${ }^{\mathrm{a}}$

\begin{tabular}{clccccc}
\hline \multirow{2}{*}{$\begin{array}{c}\text { Model } \\
\text { B }\end{array}$} & \multicolumn{2}{c}{$\begin{array}{c}\text { Unstandardised } \\
\text { Coefficients }\end{array}$} & $\begin{array}{c}\text { Standardised } \\
\text { Coefficients }\end{array}$ & \multirow{2}{*}{ T } & Sig. \\
\cline { 2 - 5 } & & Std. Error & Beta & & & \\
\hline 1 & (Constant) & 6.654 & 1.022 & & 6.512 & .000 \\
& Job Security & .409 & .047 & .284 & 8.679 & .000 \\
& Renumeration & .856 & .049 & .537 & 17.575 & .000 \\
& Management Style & .305 & .037 & .260 & 8.303 & .000 \\
\hline
\end{tabular}

a. Dependent Variable: Sustainability 
in remuneration would bring about a 0.856 unit significant effect on the sustainability of Nigerian commercial banks, while keeping other variables constant. Lastly, explanatory variable management style has $(\beta=0.305, p=.000)$, which implies that a unit change in management style would bring about a 0.305 unit significant increase in the sustainability of Nigerian commercial banks, while keeping other variables constant. The Durbin-Watson value of 2.51 was an indication that there is no autocorrelation in the sample. Based on the result, hypotheses $\mathrm{H}_{1}$, $\mathrm{H}_{2}$, and $\mathrm{H}_{3}$ were validated and accepted, which implies that job security, remuneration, and management style has a significant effect on the sustainability of Nigerian commercial banks.

To ascertain the moderating effect of organisational culture on the relationship between employee movement and the sustainability of Nigerian commercial banks, the R-Square Change in Table 9 shows the increase in variation explained by the addition of the moderating variable (organisational culture). The result in the model summary, Table 9 revealed the R-Square Change value of 0.016 and Sig. F Change of 0.000 , indicating that there is a statistically significant moderation between organisational culture and employee movement on the sustainability of Nigerian commercial banks. This implies that there is a $1.6 \%$ increase in the variation explained by the addition of organisational culture. However, with the addition of the moderator, organisational culture in the explanatory variables, the value of $\mathrm{R}^{2}(0$. $841=84.1 \%)$ and adjusted $\mathrm{R}^{2}(0.838=83.8 \%)$ revealed that the model accounted for $84.1 \%$ and $83.8 \%$ variance in the sustainability of Nigerian commercial banks, respectively. The F-statistics value of 362.951 in Table 10, with its corresponding significance of 0.000 , showed

Table 9: Model summary of the moderating effect of organizational culture on the relationship between employee movement and sustainability

\begin{tabular}{|c|c|c|c|c|c|c|c|c|c|}
\hline \multirow[b]{2}{*}{ Model } & \multirow[b]{2}{*}{$\mathbf{R}$} & \multirow[b]{2}{*}{$\begin{array}{c}\mathbf{R} \\
\text { Square }\end{array}$} & \multirow[b]{2}{*}{$\begin{array}{c}\text { Adjusted } \\
\text { R } \\
\text { Square }\end{array}$} & \multirow{2}{*}{$\begin{array}{c}\text { Std. } \\
\text { Error } \\
\text { of the } \\
\text { Estimate }\end{array}$} & \multirow[b]{2}{*}{$\begin{array}{c}\text { R } \\
\text { Square } \\
\text { Change }\end{array}$} & \multicolumn{3}{|c|}{ Change Statistics } & \multirow[b]{2}{*}{$\begin{array}{l}\text { Sig. F } \\
\text { Chang }\end{array}$} \\
\hline & & & & & & $\begin{array}{c}\text { F } \\
\text { Change }\end{array}$ & df1 & df2 & \\
\hline 1 & $.914^{\mathrm{a}}$ & .835 & .833 & 1.134 & .835 & 464.647 & 3 & 276 & .000 \\
\hline 2 & $.917^{\mathrm{b}}$ & .841 & .838 & 1.115 & .016 & 10.398 & 1 & 275 & .000 \\
\hline
\end{tabular}

a. Predictors: (Constant), Job security, remuneration, management style

b. Predictors: (Constant), Job security, remuneration, management style, organisational culture

Table 10: ANOVA $^{\mathrm{a}}$

\begin{tabular}{llccccc}
\hline \multirow{2}{*}{ Model } & $\begin{array}{c}\text { Sum of } \\
\text { Squares }\end{array}$ & Df & $\begin{array}{c}\text { Mean } \\
\text { Square }\end{array}$ & F & Sig. \\
\hline 1 & Regression & 1793.215 & 3 & 597.738 & 464.647 & $.000^{\mathrm{b}}$ \\
& Residual & 355.056 & 276 & 1.286 & & \\
& Total & 2148.271 & 279 & & & $.000^{\mathrm{c}}$ \\
\hline 2 & Regression & 1806.151 & 4 & 451.538 & 362.951 & \\
& Residual & 342.120 & 275 & 1.244 & & \\
& Total & 2148.271 & 279 & & & \\
\hline
\end{tabular}

a. Dependent Variable: Sustainability

b. Predictors: (Constant), Job security, remuneration, management style

c. Predictors: (Constant), Job security, remuneration, management style, organisational culture 
that the moderating effect of organisational culture on the relationship between employee movement and sustainability of Nigerian commercial bank's equation model was statistically significant.

Table 11 indicated that a unit change in employment movement enhanced significantly the sustainability of Nigerian commercial banks by 6.703 units. The explanatory variable job security moderated by organisational culture has $(\beta=0 . .318, p=.000)$, which implies that a unit change in job security would bring about a 0.318-unit significant enhancement in the sustainability of Nigerian commercial banks. The second explanatory variable remuneration moderated by organisational culture has $(\beta=0$. $813, \mathrm{p}=.000$ ), which implies that a unit change in remuneration would bring about a 0.813 -unit significant enhancement in the sustainability of Nigerian commercial banks while keeping other variables constant. Lastly, explanatory variable management style moderated by organisational culture has $(\beta=0.235, p=.000)$ which implies that a unit change in management style would bring about a 0.235 -unit significant increase in the sustainability of Nigerian commercial banks while organisational culture has $(\beta=0.165$, $\mathrm{p}=.000$ ), which implies that a unit change in organization culture would bring about a 0.165 unit significant increase in the sustainability of the commercial banks. Based on this result, hypothesis $\mathrm{H}_{4}$ was validated and accepted. which implies that organisational culture has a significant moderating effect on the relationship between employee movement and sustainability of commercial banks.

\section{Conclusion}

Frequent employee movement in and out of commercial banks would impact the efficiency of workers, as well as the bank's performance, which significantly influences its long-term sustainability. Therefore, it becomes pertinent for this study to pay particular attention to this subject, with core interest on the moderating effect of the organisational culture employed in the banking system in Nigeria. The numerous inconsistencies in studies regarding the exact effect of employee movement on sustainability prompted the study to empirically examine the moderating effect of organisational culture on the relationship between employee movement and the sustainability of Nigerian commercial

Table 11: Coefficients ${ }^{\mathrm{a}}$

\begin{tabular}{|c|c|c|c|c|c|c|}
\hline & \multirow{2}{*}{$\begin{array}{c}\text { Model } \\
\text { B }\end{array}$} & \multicolumn{2}{|c|}{$\begin{array}{l}\text { Unstandardised } \\
\text { Coefficients }\end{array}$} & \multirow[t]{2}{*}{$\begin{array}{c}\text { Standardised } \\
\text { Coefficients }\end{array}$} & \multirow{2}{*}{$\mathbf{t}$} & \multirow{2}{*}{ Sig. } \\
\hline & & $\begin{array}{c}\text { Std. } \\
\text { Error }\end{array}$ & Beta & & & \\
\hline \multirow[t]{4}{*}{1} & (Constant) & 6.654 & 1.022 & & 6.512 & .000 \\
\hline & Job Security & .409 & .047 & .284 & 8.679 & .000 \\
\hline & Remuneration & .856 & .049 & .537 & 17.575 & .000 \\
\hline & Management Style & .305 & .037 & .260 & 8.303 & .000 \\
\hline \multirow[t]{5}{*}{2} & (Constant) & 6.703 & 1.005 & & 6.671 & .000 \\
\hline & Job Security & .318 & .054 & .220 & 5.857 & .000 \\
\hline & Remuneration & .813 & .050 & .510 & 16.330 & .000 \\
\hline & Management Style & .235 & .042 & .201 & 5.588 & .000 \\
\hline & $\begin{array}{l}\text { Organisational } \\
\text { Culture }\end{array}$ & .165 & .051 & .149 & 3.225 & .000 \\
\hline
\end{tabular}

a. Dependent Variable: Sustainability

b. Predictors in the Model: (Constant), Management style, remuneration, job security 
banks. The hypotheses of the study were tested and the results revealed that employee movement has a significant effect on the sustainability of Nigerian commercial banks. Specifically, employee movement constructs, such as job security, remuneration, and management style, have significant effects on the sustainability of the Nigerian commercial banks. Furthermore, organisational culture has a significant moderating effect on the relationship between employee movement and the sustainability of commercial banks. Given the moderating effect of organisational culture on the relationship between employee movement and the sustainability of Nigerian commercial banks, employee movement has an overall significant positive effect on the sustainability of Nigerian commercial banks. Specifically, the various employee movement measures (job security, remuneration, and management style) individually impacted the sustainability of Nigerian commercial banks significantly.

The managerial implication of the study is that the negative effect of employee movement on the sustainability of Nigerian commercial banks can be addressed by adopting and implementing an employee-friendly organisational culture. However, the present study was not without limitations. First, the study was geographically limited to selected commercial banks in Calabar, Cross River State. The findings can be different when the variables are investigated in other countries or regions. Second, the onetime data collection using a questionnaire without utilising a longitudinal survey over a period of time posed a limitation to the research. Lastly, the study only investigated three constructs of employee movement, which appear to miss out some other relevant variables that may also have significant effects on the sustainability of commercial banks. Thus, future research can integrate other related variables of employee movement in the study to investigate their influence on the sustainability of banks in other countries and continent with a different cultural background, as well its applicability in different sectors of the economy, like education, oil, and gas, telecommunication, etc.

\section{Acknowledgements}

The authors would like to thank the reviewers, including the associate editor of the journal, for his valuable comments and suggestions that helped improve the quality of this paper. Also, the authors thank all the researchers whose work were use in this study.

\section{References}

Ade, A., Musibau, A., Idi-Iroko, R., Anthony, B., \& Tolani, A. (2015). Impact of employee turnover in small and medium construction firms: A literature review. International Journal of Engineering Research \& Technology, 4(2), 976-984. DOI: IJERTV4IS020257

Adnan, I. (2010). Employee turnover: Causes, consequences and retention strategies in the Saudi organizations. The Business Review, Cambridge, 16(2), 275-281.

Ali, H. A. (2015). Investigating factors that influence employees' turnover intention: A review of existing empirical works. International Journal of Business and Management, 10(12), 152-166. http:// dx.doi.org/10.5539/ijbm.v10n12p152

Amah, E., \& Daminabo-Weje, M. (2013). Corporate culture: A tool for control and effectiveness in organizations. Research on Humanities and Social Sciences, 3(15), 4249.

Anders, D., \& Bard, K. (2010). Exploring the relative and combined influence of mastery approach goals and work intrinsic motivation on employee turnover intention. Personnel Review, 39(5), 622-638. DOI: $10.1108 / 00483481011064172$

Armstrong, M. (2009). Human resources management practice (11th ed.). London: Kogan Page.

Batermen, T. S., \& Snell, S. A. (1999). Management: Building competitive advantage (4th ed.) Boston: McGraw-Hill. 
Bosomtwe, T., \& Obeng, B. (2018). The link between organizational culture and turnover intention among employees in Ghana. International Journal of Contemporary Research and Review, 9(8), 2095120958. DOI: https://doi.org/10.15520/ ijcrr/2018/9/08/566

Chowdhury, A., \& Nazmul, H. (2017). Factors affecting employee turnover and sound retention strategies in business organization: A conceptual view. Problems and Perspectives in Management, 15(1), 63-71. Doi:10.21511/ppm.15 (1).2017.06

David, C., \& Sebastian, S. (2016). Employees, sustainability and motivation: Increasing employee engagement by addressing sustainability and corporate social responsibility. Research in Hospitality Management, 6(1), 69 -76. https://dx.doi. org/10.2989/RHM.2016.6.1.9.1297

Deal, T. E., \& Kennedy, A. A. (2000). Corporate cultures: The rites and rituals of corporate life. Harmandsworth: Basic Books.

Dessler, G. (2008). Human resources management $\left(11^{\text {th }}\right.$ ed.). Upper Saddle River, NJ: Prentice Hall.

Effiom, M., \& Anietie, E. (2018). Labour turnover and the performance of Nigerian firms. Journal of Research in National Development, 16(1), 20-28

Eric, O. K. (2018). Organisational culture and employee turnover: Evidence from Ghana. Journal of Economics, Management and Trade, 21(2), 1-11. DOI: 10.9734/ JEMT/2018/39062

Esra, A. Çiçekb, K., \& Kiyakc, M. (2011). The effect of organizational culture on organizational efficiency: The moderating role of organizational environment and CEO values. Procedia Social and Behavioral Sciences, 24, 1560-1573. Doi:10.1016/j. sbspro.2011.09.092

Francis, M. (2015). Factors influencing labour turnover in commercial banks in Kenya. Department of Business Administration.
School of Business, University of Nairobi. Retrieved from https:// e63febf5840da8861c74cdda6df6750d35. pdf

Girma, T. N. (2019). The effects of organizational culture on turnover intention: The mediating role of job satisfaction: A case of Oromia Forest and Wild Life Enterprise. African Journal of Business Management, 13(2), 82-89. DOI: 10.5897/AJBM2018.8612

Hair JR, J. F., Black, W. R., Babin, B. J., \& Anderson, R. E. (2010). Multivariate Data Analysis $\left(7^{\text {th }}\right.$ ed.). Upper Saddle River, NJ, Prentice Hall.

Hill, N. C. (1979). Increasing managerial effectiveness: Keys to management and motivation. Menlo Park, Calf: AddisonWesley Publishing.

Ian, T., \& Jonathan, W. (2007). The importance of management style in labour retention. International Journal of Sociology and Social Policy, 27(1/2), 5-18. DOI: 10.1108/01443330710722724

Idiegbeyan-Ose, J., Opeke, R., Nwokeoma, N., \& Osinulu, F. (2018). Influence of organisational culture on turnover intention of library staff in private University Libraries, South-West Nigeria. Academy of Strategic Management Journal, 17(4), 1-13. DOI: 1 1939-6104-17-4-241

Kline, R. B. (2010). Principles and practice of structural equation modelling ( $3^{\text {rd }}$ ed.). New York: Guilford Press.

Kotter, J. P., \& Heskett, J.L. (1992). Corporate culture and performance. New York: Free Press.

Kunu, E., FranÇois, M., Patience, A., \& Mathias, K. (2017). The effect of employee turnover on the performance of Zoomlion Ghana Limited. Journal of Business and Economic Development, 2(2), 116-122. Doi: 10.11648/j.jbed.20170202.17

Likert, R. (1967). The human organization: Its management and value $\left(1^{\text {st }} \mathrm{ed}\right.$.). New York: McGraw Hill. 
Linz, S., Good, L., \& Huddleston, P. (2006). Worker morale in Russia: An exploratory study. Journal of Managerial Psychology, 21(5), 415-437. DOI: 10.1108/02683940610673951

Marwan, A., Bader, A., Hamzah, A., \& Mohammad, M. (2016). What drives employee's involvement and turnover intentions: Empirical investigation of factors influencing employee involvement and turnover intentions? International Review of Management and Marketing, 6(2), 298-306.

Meaghan, S., \& Nick, B. (2002). Voluntary turnover: Knowledge management -friend or foe? Journal of Intellectual Capital, 3(3), 303-322. DOI 10.1108/1469 1930210435633

Meier, K., \& Hicklin, A. (2007). Employee turnover and organizational performance: Testing a hypothesis from classical public administration. Journal of Public Administration Research and Theory, 18, 573-590. Doi:10.1093/jopart/mum028

Michael O., \& Crispen, C. (2009). Employee retention and turnover: Using motivational variables as a panacea. African Journal of Business Management, 3(8), 410-415. DOI: 10.5897/AJBM09.125.

Mutua, C. M., \& Simba, F. T. (2017). Effect of organizational culture on employee turnover: A case study of technical University of Mombasa. The Strategic Journal of Business \& Change Management, 4(1), 1-14.

Naidoo, R. (2018). Role stress and turnover intentions among information technology personnel in South Africa: The role of supervisor support. Journal of Human Resource Management, 16(0), 1-10. https:// doi.org/ 10.4102/sajhrm.v16i0.936

Nnamani, E., \& Agu, P. (2012). The impact of organizational culture on employee performance a study of selected Manufacturing Industry in Enugu. Asian
Journal of Business Management Studies, 3(2), 13-19.

Nqwenelwa, N. (2013). Factors contributing to employee turnover intention at a selected company in the Cape Town Clothing Industry. Department of Business Administration, Faculty of Business, Cape Peninsula University of Technology.

Nyaga, R. (2015). Assessment of employee turnover on organizational efficiency: A case study of International Livestock Research Institute (ILRI). Chandaria School of Business, United States International University-Africa.

Obiero, O. (2014). Factors influencing high staff turnover in commercial banks in Kenya: A case of commercial bank in Africa. Department of Project Management. School of Business, University of Nairobi.

Olusegun, O. (2012). Influence of motivation on turnover of library personnel in some public universities in South West Nigeria. Library Philosophy and Practice (e-journal), 722. https://digitalcommons.unl.edu/libphil prac/722

Osibanjo, O. A., \& Adeniji, A. A. (2013). Impact of organizational culture on human resource practices: A study of selected Nigerian Private Universities. Journal of Competitiveness, 5(40), 115-133. DOI: 10.7441/joc.2013.04.07.

Pietersen, C., \& Oni, O. (2014). Employee turnover in a regional commercial bank. Mediterranean Journal of Social Sciences, 5(27), 371-380. Doi:10.5901/mjss.2014. v5n27p371

Price, A. (1997). Human resources management in a business context. London: International Thompson Business Press.

Rasoava, R. (2015). Employee turnover rate and organizational performance in South Africa. Problems and Perspectives in Management, 13(4-1), 240-253.https://orcid.org/0000-00 02-4631- 4801 
Ravasi, D., \& Schultz, M. (2006). Responding to original Identity threats: Exploring the role of organizational culture. Academy of management Journal, 49(3), 433-458. DOI: 10.5465/AMJ.2006.21794663

Renata, K. (2019). Business model as a concept of sustainability in the banking sector. Sustainability, 12(111), 1-12; doi: 10.3390/ su12010111

Santript, S., \& Ambalika, S. (2013). Employee turnover in banking sector: Empirical evidence. Journal of Humanities and Social Science, 11(5), 57-61.

Shinwoo, L. (2018). Employee turnover and organizational performance in U.S. Federal Agencies. American Review of Public Administration, 48(6), 522-534. DOI: 10. 1177/0275074017715322

Stankevicienea, J., \& Nikonorova, M. (2014). Sustainable value creation in commercial banks during financial crisis. Procedia Social and Behavioral Sciences, 110, 1197 $-1208$

Steers, R., \& Porter, L. (1991). Motivation and work behavior. New York: McGraw Hill.

Tamunomiebi, M. D. (2003). Labour economics and relations. Owerri: Daatim Publishers.
Testa, B. (2008). Early engagement, long relationships? Workforce Management, 87(15), 27-31.

Tommasetti, A., Antonelli, V., D’Alessio, R., \& Torre, C. (2019) Relationships between the determinants of sustainable performance and employee motivation: A Structural Equation Model. Journal of Service Science and Management, 12, 58-76. https://doi. org/10.4236/jssm.2019.121004

Ubeku, A., (1975). Personal management in Nigeria. Benin: Ethiope Publishing Corporation.

Wong, F. Y., Jo, A. H., \& Aziany, R., A. (2016). The influence of sustainable organization practices and employee well-being on turnover intention. Journal of Social Sciences \& Humanities, 24(S), 47 - 62.

Zeeshan, A., Sarwat, S., Mishal, K., Imam, A., \& Muhammad, A. (2016). Impact of employee turnover on organisational effectiveness in Tele Communication Sector of Pakistan. Journal of Business and Management, 18(11), 128-136. DOI: $10.9790 / 487 \mathrm{X}-$ 181104128136. 